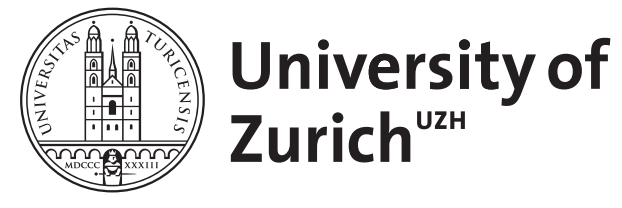

Zurich Open Repository and Archive

University of Zurich

University Library

Strickhofstrasse 39

CH-8057 Zurich

www.zora.uzh.ch

Year: 2021

Synthesis and Characterization of Bidentate $\left(\mathbf{P}^{N}\right)$ Gold $(I I I)$ FluorideComplexes : ReactivityPlatforms forReductiveEliminationStudies

Genoux, Alexandre ; Biedrzycki, Michał ; Merino, Estíbaliz ; Rivera-Chao, Eva ; Linden, Anthony ; Nevado, Cristina

Abstract: A new family of cationic, bidentate $\left(\mathrm{P}^{N}\right)$ gold(III) fluoridecomplexeshasbeenpreparedandadetailedcharacteriz

DOI: https://doi.org/10.1002/anie.202009359

Posted at the Zurich Open Repository and Archive, University of Zurich ZORA URL: https://doi.org/10.5167/uzh-199506

Journal Article

Accepted Version

Originally published at:

Genoux, Alexandre; Biedrzycki, Michał; Merino, Estíbaliz; Rivera-Chao, Eva; Linden, Anthony; Nevado, Cristina (2021). Synthesis and Characterization of Bidentate $\left(\mathrm{P}^{N}\right)$ Gold(III)FluorideComplexes : ReactivityPlatforms $4164-4168$.

DOI: https://doi.org/10.1002/anie.202009359 


\title{
Synthesis and Characterization of Bidentate (P^N)Gold(III) Fluoride Complexes: Reactivity Platforms for Reductive Elimination Studies
}

\author{
Alexandre Genoux, ${ }^{[a]}$ Michał Biedrzycki, ${ }^{[a]}$ Estíbaliz Merino, ${ }^{[a, b]}$ Eva Rivera, ${ }^{[a]}$ Anthony Linden ${ }^{[a]}$ and \\ Cristina Nevado*[a] \\ [a] Alexandre Genoux, Michał Biedrzycki, Dr. Estíbaliz Merino, Eva Rivera, Prof. Dr. Anthony Linden and Prof. Dr. Cristina Nevado \\ Department of Chemistry, University of Zurich \\ Winterthurerstrasse 190, 8057 Zürich (Switzerland) \\ E-mail: cristina.nevado@chem.uzh.ch \\ [b] Current address: \\ Department of Organic and Inorganic Chemistry \\ Chemical Research Institute Andrés M. del Río (IQAR) University of Alcalá \\ 28805-Alcalá de Henares (Madrid, Spain)
}

Supporting information for this article is given via a link at the end of the document.

\begin{abstract}
A new family of cationic, bidentate $\left(\mathrm{P}^{\wedge} \mathrm{N}\right)$ gold(III) fluoride complexes has been prepared and a detailed characterization of the gold-fluoride bond has been carried out. Our results correlate with the observed reactivity of the fluoro ligand, which undergoes facile exchange with both cyano and acetylene nucleophiles. The resulting $\left(\mathrm{P}^{\wedge} \mathrm{N}\right)$ arylgold(III)C(sp) complexes have enabled the first study of reductive elimination on $\left(\mathrm{P}^{\wedge} \mathrm{N}\right)$ gold(III) systems demonstrating that $\mathrm{C}\left(\mathrm{sp}^{2}\right)-\mathrm{C}(\mathrm{sp})$ bond formation occurs at higher rates than those reported for analogous phosphine-based monodentate systems.
\end{abstract}

\section{Introduction}

Late transition metal fluorides raise interesting questions in bonding and reactivity compared to their heavier halide analogues. ${ }^{[1]}$ Highly oxidized palladium and nickel fluoride complexes have been isolated and intensively studied because of their crucial role in $\mathrm{C}-\mathrm{H}$ activation, fluorination, oxidation, and cross-coupling reactions. ${ }^{[2,3]}$ In contrast, and despite the emergence of gold(I)/gold(III) catalysis as a complementary tool in this context, ${ }^{[4]}$ gold(III) fluoride complexes have remained largely unexplored until recently. Numerous gold-catalyzed oxidative couplings forging $\mathrm{C}\left(\mathrm{sp}^{2}\right)-\mathrm{C}\left(\mathrm{sp}^{2}\right)$ and $\mathrm{C}\left(\mathrm{sp}^{2}\right)-\mathrm{C}\left(\mathrm{sp}^{3}\right)$ bonds employed electrophilic fluorinating reagents to enable gold(I)/gold(III) redox cycles and invoked gold(III) fluorides as key intermediates. ${ }^{[5]}$ However, isolated organogold fluoride complexes are scarce as they represent an extreme mismatched pair according to the HSAB theory. ${ }^{[6]}$ Seminal work by Toste on the oxidation of $(\mathrm{NHC})$ gold $(\mathrm{I})$ alkyl species with $\mathrm{XeF}_{2}$ resulted in the isolation of the first gold(III) fluorides cis-[(NHC)Aull'AlkylF $\left.F_{2}\right]$. These complexes react with boronic acids enabling the formation of $\mathrm{C}\left(\mathrm{sp}^{2}\right)-\mathrm{C}\left(\mathrm{sp}^{3}\right)$ bonds (Scheme 1a). ${ }^{[6 \mathrm{~d}]}$ Using a complementary approach devoid of oxidizing conditions, our group has also prepared and characterized a set of novel $\left[\left(C^{\wedge} N\right) A u^{I I I} F_{2}\right]$, $\left[\left(C^{\wedge} N\right) A u^{\prime \prime \prime} A r y l F\right]$ and $\left[\left(C^{\wedge} N\right) A u^{\prime \prime \prime} A l k y l F\right]$ complexes which, upon transmetallation with organoboron reagents, enabled the study of the $\mathrm{C}\left(\mathrm{sp}^{2}\right)-\mathrm{C}\left(\mathrm{sp}^{2}\right)$ and $\mathrm{C}\left(\mathrm{sp}^{2}\right)-\mathrm{C}\left(\mathrm{sp}^{3}\right)$ reductive elimination processes (Scheme 1b). ${ }^{[6 g]}$

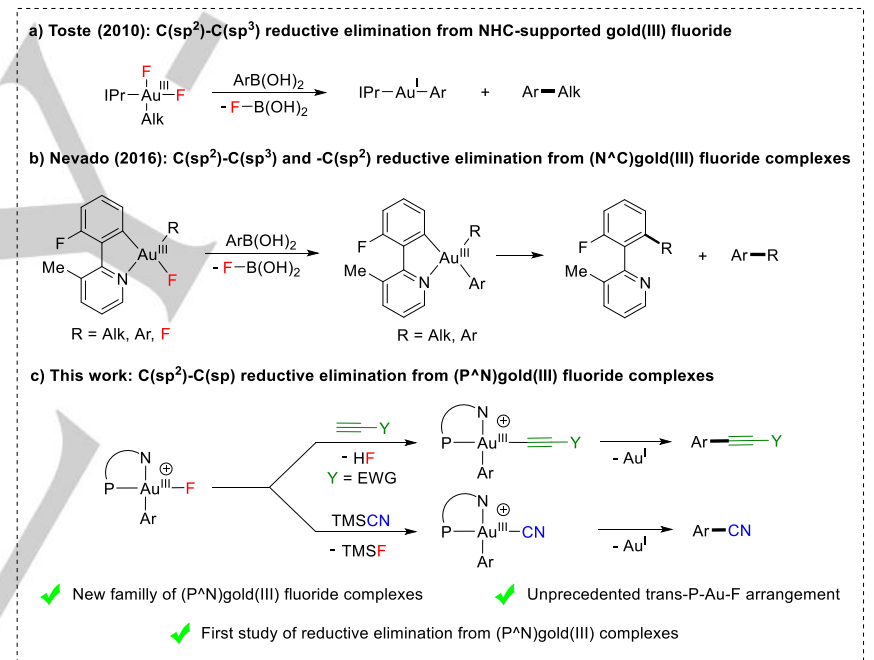

Scheme 1. Synthesis and reactivity of gold(III) fluoride complexes towards C-C bonds formation.

Recent examples focused on the structural characterization of gold(III) fluorides have also been reported by Riedel, ${ }^{[6 h, ~ 6 i]}$ Menjón ${ }^{[6]]}$ and Dutton, ${ }^{[6 \mathrm{k}]}$ respectively. Interestingly, and despite these significant advances, the reactivity of gold(III) fluorides in the context of $\mathrm{C}\left(\mathrm{sp}^{2}\right)$ $\mathrm{C}(\mathrm{sp})$ reductive elimination has not been explored yet even if they have been proposed to be crucial reaction intermediates in this type of $\mathrm{C}-\mathrm{C}$ bond forming reactions. ${ }^{[59-1]}$ Herein, we present a new family of bidentate $\left(P^{\wedge} \mathrm{N}\right)$ arylgold(III) fluorides featuring an unprecedented trans-P-Au-F arrangement. A detailed structural and computational characterization of the Au $u^{\prime \prime \prime}-\mathrm{F}$ bond has been carried out correlating the ligand exchange ability of the fluoride with both cyano and acetylene nucleophiles. In addition, we present the first study on the $\mathrm{C}\left(\mathrm{sp}^{2}\right)-\mathrm{C}(\mathrm{sp})$ bond forming reductive elimination from $\left(\mathrm{P}^{\wedge} \mathrm{N}\right)$ gold $(\mathrm{III})$ complexes and demonstrate that this process occurs at higher rates than those reported for analogous phosphine-based monodentate systems (Scheme 1c). 


\section{Results and Discussion}

The synthesis of different arylgold(III) fluorides complexes (3a-d) was accomplished from the corresponding (MeDalPhos)gold(I ${ }^{[7]}$ chloride $\left(\mathbf{1} a, R^{1}=A d, R^{2}=M e\right)$ through a two-step process including oxidative addition with Ar-I followed by $\mathrm{I} / \mathrm{F}$ ligand exchange with $\mathrm{AgF}$ in dichloromethane $\left(\mathrm{CH}_{2} \mathrm{Cl}_{2}\right)$ at $25 \stackrel{\circ}{\circ} \mathrm{C}$ (Scheme 2). ${ }^{[4,6 g, 8]}$ The complexes were stable in solution for approximately two days at room temperature under inert atmosphere. In order to evaluate steric effects around the metal center, 2-(di-tert-butylphosphino)- $\mathrm{N}, \mathrm{N}$-dimethylaniline and 2-(di1 -adamantylphosphino)phenyl-piperidine ligands were employed to synthesize complexes $\mathbf{3 e}$ and $\mathbf{3} \mathbf{f}$ following the same two-step procedure (Scheme 2).

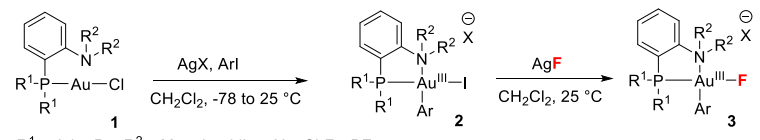
$\mathrm{R}^{1}=\mathrm{Ad}, t \mathrm{Bu} ; \mathrm{R}^{2}=\mathrm{Me}$, piperidine; $\mathrm{X}=\mathrm{SbF}_{6}, \mathrm{BF}_{4}$

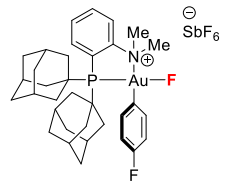

Step 1: 2 a, $85 \%$ Step 2: $\mathbf{3 a} 95 \%$

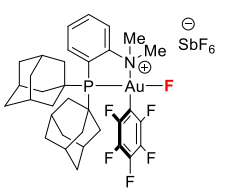

Step 1: 2 d, $75 \%$
Step 2: $\mathbf{3 d}, 90 \%$

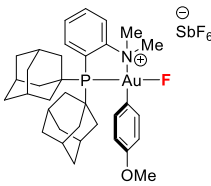

Step 1: 2 b, $89 \%$

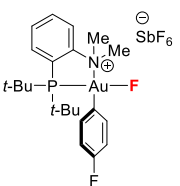

Step 1: $2 \mathbf{e}, 89 \%$
Step 2: 3 e, $94 \%$

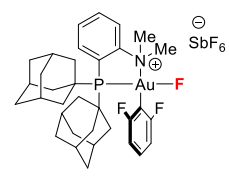

Step 1: 2 c, $81 \%$

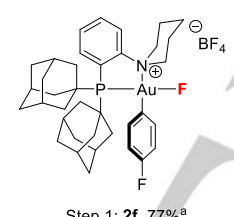

Step 1: $2 \mathbf{2 f}, \mathbf{7 7} \%^{\circ}$
Scheme 2. Synthesis of novel $\left(P^{\wedge} N\right)$ arylgold(III) fluoride complexes. See ref. 12 for experimental details. ${ }^{a}$ For $3 \mathbf{3 f}, \mathrm{AgBF}_{4}$ was used instead of $\mathrm{AgSbF}_{6}$ due to the low solubility of the nascent $\mathrm{SbF}_{6}$ salt in $\mathrm{CH}_{2} \mathrm{Cl}_{2}$.

Single crystals of $\mathbf{3 a}, \mathbf{3} \mathbf{b}, \mathbf{3} \mathbf{d}$ and $\mathbf{3 e}$ were obtained by slow diffusion of $n$-hexanes into a concentrated $\mathrm{CH}_{2} \mathrm{Cl}_{2}$ solution of each complex at $-30{ }^{\circ} \mathrm{C}$ (Figure 1). The analysis of the structures obtained by $\mathrm{X}$-ray diffraction shows that all compounds crystallize as monomeric species in which the metal center has a distorted square planar geometry. The trans relationship between $\mathrm{P}$ and $\mathrm{F}$, unprecedented for gold(III), was also confirmed by the high ${ }^{2} J_{P, F}$ coupling constants observed in the ${ }^{31} \mathrm{P}\left\{{ }^{1} \mathrm{H}\right\}\left(\delta_{\mathrm{P}}=71.59 \mathrm{ppm}, \mathrm{d}\right.$, ${ }^{2} J_{P, F}=100.5 \mathrm{~Hz}$; for $\left.3 a\right)$ and ${ }^{19} \mathrm{~F}$ NMR spectra $\left(\delta_{\mathrm{F}}=-143.8 \mathrm{ppm}\right.$, d, ${ }^{2} J_{P, F}=100.5 \mathrm{~Hz}$; for $\left.3 a\right){ }_{.}^{[2 i, 8]}$ It is noteworthy that the Au-F distances correlate with the substitution pattern of the aryl ligand: the Au- $\mathrm{F}$ bond length increases for electron-deprived compared to more electron-rich counterparts $\left(\mathrm{d}_{\mathrm{Au}-\mathrm{F}}\right.$ for $\mathbf{3 a}(p-\mathrm{F}): 2.023 \AA$; $3 \mathbf{b}$ $(p-\mathrm{OMe}): 2.006 \AA$; $3 \mathbf{d}(5 \mathrm{~F}): 2.133 \AA$ ) (Figure 1 and Table 1).

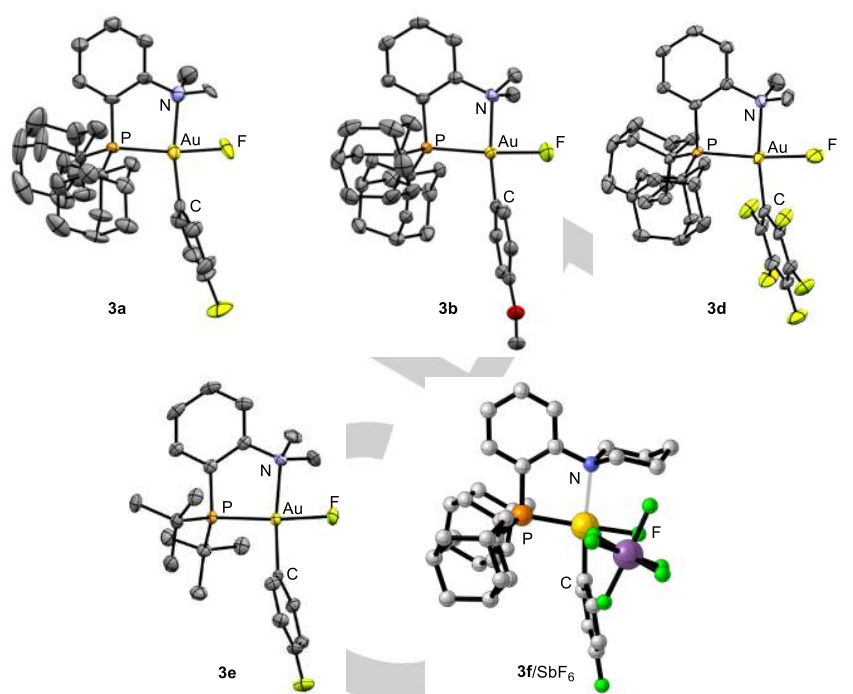

Figure 1. X-ray crystal structures of $\mathbf{3 a}, \mathbf{3 b}, \mathbf{3 d}, \mathbf{3 e}$ shown as $50 \%$ ellipsoids $(\mathrm{H}$ and $\mathrm{SbF}_{6}$ omitted for clarity). Computed structure of $3 \mathbf{f} / \mathrm{SbF}_{6}$ (B3LYP, 6$31 \mathrm{G}(\mathrm{d}, \mathrm{p}), \mathrm{Au}$ (SDDAll), solvent (smd) =dichloromethane.

Despite numerous attempts, the crystallization of $\mathbf{3 f}$ was not possible due to its lability in solution. In order to obtain further insights, the structure of this complex (together with those of 3a and $3 \mathbf{e}$ for the sake of comparison) was optimized by DFT calculations. Bond distances and angles calculated for all three compounds $\mathbf{3 a}, \mathbf{3 e}$ and $\mathbf{3} \mathbf{f}$ can be found in Table 1. The distances and angles obtained for the computed structures of $3 a$ and $3 e$ deviate minimally from those measured in the crystals $\left(\Delta \mathrm{d}_{\max }\right.$ : $0.07 \AA ; \Delta \alpha_{\max }: 2.0^{\circ}$ ), thus rendering a comparative analysis with the obtained data for complex $3 f$ meaningful.

Table 1. Selected $X$-ray and computed bond distances $(\AA)$ and angles $\left(^{\circ}\right)$ for $\mathbf{3 a}$ 3b, 3d, 3e and 3f/SbF 6 (B3LYP, 6-31G(d,p), Au (SDDAll), solvent (smd) $=$ dichloromethane.

\begin{tabular}{|c|c|c|c|c|c|c|c|}
\hline \multirow{2}{*}{$\begin{array}{c}\text { Angles } \\
\left({ }^{\circ}\right)\end{array}$} & \multicolumn{2}{|c|}{$3 a$} & \multirow{2}{*}{$\begin{array}{c}\text { 3b } \\
\text { X-ray }\end{array}$} & $3 d$ & \multicolumn{2}{|c|}{$3 e$} & \multirow{2}{*}{$\begin{array}{c}3 \mathbf{f f} / \mathrm{SbF}_{6} \\
\text { DFT }\end{array}$} \\
\hline & X-ray & DFT & & X-ray & X-ray & DFT & \\
\hline $\mathrm{N}-\mathrm{Au}-\mathrm{F}$ & $\begin{array}{c}86.1 \\
(4)\end{array}$ & 88.0 & $\begin{array}{c}87.5 \\
(1)\end{array}$ & $\begin{array}{c}88.0 \\
(1)\end{array}$ & $\begin{array}{c}87.9 \\
(1)\end{array}$ & 88.3 & 93.9 \\
\hline C-Au-F & $\begin{array}{c}83.7 \\
(5)\end{array}$ & 84.2 & $\begin{array}{c}85.6 \\
(1)\end{array}$ & $\begin{array}{c}83.5 \\
(1)\end{array}$ & $\begin{array}{c}85.6 \\
(2)\end{array}$ & 84.3 & 80.1 \\
\hline P-Au-C & $\begin{array}{c}103.1 \\
(4)\end{array}$ & 102.0 & $\begin{array}{c}100.9 \\
(1)\end{array}$ & $\begin{array}{c}102.3 \\
(7)\end{array}$ & $\begin{array}{c}99.3 \\
(1)\end{array}$ & 101.4 & 100.5 \\
\hline \multirow{2}{*}{$\begin{array}{c}\text { Distances } \\
(\AA)\end{array}$} & \multicolumn{2}{|c|}{$3 a$} & $3 b$ & $3 d$ & \multicolumn{2}{|c|}{$3 e$} & $3 f$ \\
\hline & X-ray & DFT & X-ray & X-ray & X-ray & DFT & DFT \\
\hline$A u-P$ & $\begin{array}{c}2.278 \\
(3)\end{array}$ & 2.351 & $\begin{array}{c}2.299 \\
(1)\end{array}$ & $\begin{array}{c}2.309 \\
(1)\end{array}$ & $\begin{array}{c}2.270 \\
(1)\end{array}$ & 2.344 & 2.356 \\
\hline $\mathrm{Au}-\mathrm{F}$ & $\begin{array}{c}2.023 \\
(8)\end{array}$ & 2.033 & $\begin{array}{c}2.006 \\
(2)\end{array}$ & $\begin{array}{c}2.133 \\
(2)\end{array}$ & $\begin{array}{c}2.000 \\
(3)\end{array}$ & 2.030 & 2.034 \\
\hline
\end{tabular}

Interestingly, the additional steric hindrance imposed by the piperidine moiety on the $\mathrm{N}$ ligand seems to have the strongest influence in disrupting the square planar geometry of the complexes, as reflected on the smaller $\mathrm{C}-\mathrm{Au}-\mathrm{F}$ angle determined for $\mathrm{N}$-piperidine complex $3 \mathbf{f}\left(80.1^{\circ}\right)$ compared to $\mathrm{N}(\mathrm{Me})_{2}$ 
derivatives 3a: $84.2^{\circ}\left(83.7(5)^{\circ}\right.$ from $X$-ray $)$ and $3 \mathbf{e}: 84.3^{\circ}\left(85.6(2)^{\circ}\right)$ from $X$-ray) (Table 1$)$. In contrast, the trans $-\left({ }^{2} J_{P-F}\right)$ coupling constant seems to be much more influenced by the substituents on the $P$ atom with 100.5 and $100.0 \mathrm{~Hz}$ values obtained for adamantly-substituted complexes $\mathbf{3 a}$ and $\mathbf{3 f}$ vs. $107.2 \mathrm{~Hz}$ measured for tBu-substituted one (3e) (Table 2). ${ }^{[9]}$

Previously, the magnitude of the trans- $\left({ }^{2} J_{\mathrm{P}-\mathrm{X}}\right)$ coupling constant in both gold(I) $\left(X={ }^{13} \mathrm{C}\right)^{[10 a]}$ and $\operatorname{Pd}(\mathrm{II})\left(X={ }^{15} \mathrm{~N}\right)^{[10 \mathrm{~b}]}$ complexes has been used to characterize the electronic nature of the metal: typically, larger coupling constants are correlated with higher nuclear charges on the two chelating atoms of the ligands, thus rendering a more electropositive metal center. In the case of complexes $\mathbf{3 a}, \mathbf{3 e}$ and $\mathbf{3} \mathbf{f}$ we can observe how despite the larger ${ }^{2} J_{\mathrm{P}-\mathrm{F}}$ observed for $\mathrm{tBu}_{3} \mathrm{P}$-ligated complex $3 \mathrm{e}(107.2 \mathrm{~Hz})$, the charge on gold $\left(\delta_{\mathrm{Au}}=+0.724\right)$ is similar to that calculated for 3a $\left(\delta_{\mathrm{Au}}=+0.725\right)$ and both are smaller compared to that calculated for $\mathbf{3 f}\left(\delta_{\mathrm{Au}}=+0.750\right)$. These results can be explained on the basis of the strong influence that the $\mathrm{N}$ ligand exerts on the overall polarization of the Au-F bond $\left(\delta_{N}=-0.509\right.$ for $3 a$ and $=-0.525$ for 3f) and which is not reflected on the ${ }^{2} J_{P-F}$. In fact, the overall distortion imposed by the sterics around the $\mathrm{N}$ atom compromises the overall $\sigma$ donor ability of the bidentate ligand resulting in a more electropositive metal $\left(\delta_{\mathrm{Au}}=+0.750\right)$ and thus a more polarized Au-F bond $\left(\delta_{F}=-0.594\right)$ in $3 f^{[11]}$

Table 2. ${ }^{2} J_{P-F}(\mathrm{~Hz})$ and partial charges $(\delta)$ per atom for complexes $\mathbf{3 a}, \mathbf{3 e}$ and $\mathbf{3 f}$. Natural Population Analysis based on the optimized structures obtained with B3LYP, 6-31G(d,p), Au (SDDAll), solvent (smd) =dichloromethane.

\begin{tabular}{cccc}
\hline & 3a & 3e & 3f \\
\hline${ }^{2} J_{(\mathrm{P}-\mathrm{F})}$ & 100.5 & 107.2 & 100.0 \\
$\delta_{\mathrm{Au}}$ & +0.725 & +0.724 & +0.750 \\
$\delta_{\mathrm{F}}$ & -0.590 & -0.587 & -0.594 \\
$\delta_{\mathrm{P}}$ & +1.194 & +1.167 & +1.167 \\
$\delta_{\mathrm{N}}$ & -0.509 & -0.507 & -0.525 \\
$\delta_{\mathrm{C}}$ & -0.177 & -0.176 & -0.162 \\
\hline
\end{tabular}

The calculated Wiberg bond indexes (WBI) for Au-F bond are small (3a: $0.330,3 e: 0.339$ and $\left.\mathbf{3 f} \cdot \mathbf{S b F}_{6}: 0.321\right)$. Further, a local description of the occupancy in NBO confirms the polarized nature of the Au-F in these complexes. ${ }^{[11]}$ Overall, and beyond small differences within the individual complexes, these results reveal a strong ionic character of the $\mathrm{Au}-\mathrm{F}$ bond and strongly suggests a high nucleophilic and labile character for the fluoride ligands in these systems. We aimed to capitalize on these features in order to study $\mathrm{C}\left(\mathrm{sp}^{2}\right)-\mathrm{C}(\mathrm{sp})$ reductive elimination on gold(III). In contrast to the well-characterized $\mathrm{C}\left(\mathrm{sp}^{3}\right)-\mathrm{C}\left(\mathrm{sp}^{3}\right)$, $\mathrm{C}\left(\mathrm{sp}^{2}\right)-\mathrm{C}\left(\mathrm{sp}^{2}\right)$ and $\mathrm{C}\left(\mathrm{sp}^{2}\right)-\mathrm{C}\left(\mathrm{sp}^{3}\right)$ reductive eliminations, ${ }^{[12]}$ the analogous process for $\mathrm{sp}$-hybridized systems has remained rather elusive. Further, while seminal work by Bourissou et al has demonstrated the utility of $\left(\mathrm{P}^{\wedge} \mathrm{N}\right)$ ligands to study previously inaccessible oxidative addition processes and associated gold(I)/gold(III) catalytic cycles, ${ }^{[4-h, 7]}$ their utilization towards the study of the opposite process, i.e. reductive elimination, is yet to be reported.
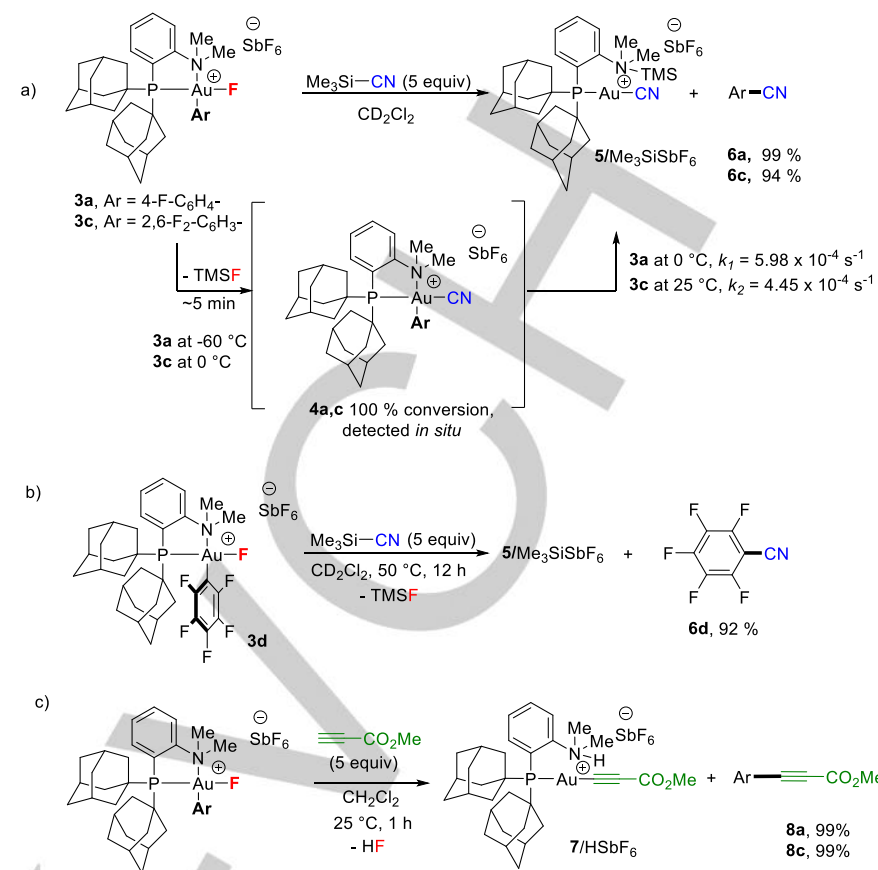

3a, $\mathrm{Ar}=4-\mathrm{F}-\mathrm{C}_{6} \mathrm{H}_{4}-$

$3 \mathrm{ac}, \mathrm{Ar}=4-\mathrm{F}-\mathrm{C}_{6} \mathrm{H}_{4}^{-}$
$3 \mathrm{c}, \mathrm{Ar}=2,6-\mathrm{F}_{2}-\mathrm{C}_{6} \mathrm{H}_{3}$

d)
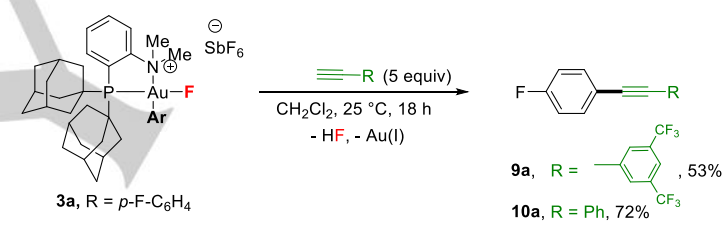

Scheme 3. Reactivity of gold(III) fluorides 3 towards $\operatorname{TMSCN}(a, b)$ and alkynes $(\mathrm{c}, \mathrm{d})$ and subsequent $\mathrm{C}\left(\mathrm{sp}^{2}\right)-\mathrm{C}(\mathrm{sp})$ reductive elimination studies.

To our delight the reaction of $3 a$ with TMSCN at $25^{\circ} \mathrm{C}$ produced quantitatively, 4-fluorobenzonitrile $\mathbf{6 a}$ together with a new gold(I)cyano complex $\left(5 / \mathrm{Me}_{3} \mathrm{SiSbF}_{6}\right)$, whose structure could be confirmed by independent preparation through an alternative route. ${ }^{[8]}$ Intrigued by these results, the same reaction was conducted at $-60{ }^{\circ} \mathrm{C}$ and monitored by in situ ${ }^{19} \mathrm{~F}$ NMR. ${ }^{[8]}$ In this case, a new complex could be detected and assigned as the expected arylgold(III) cyanide intermediate $4 \mathbf{a}^{\left[{ }^{[8,13]}\right.}$ After warming up to $0^{\circ} \mathrm{C}, \mathbf{4 a}$ evolved exclusively to $6 \mathbf{a}$ (Scheme $3 \mathrm{a}$ ). Temporal concentrations of cyano complex $4 \mathbf{a}$ and product $6 \mathbf{a}$ were calculated using 2-fluoronaphtalene as internal standard. The consumption of $\mathbf{4 a}$ followed a clean irreversible first-order decay $\left\{-\mathrm{d}[\mathbf{4 a}] / \mathrm{d} t=k_{1}[\mathbf{4 a}]\right\}$ up to conversions higher than $95 \%$. The firstorder rate constant $\left(k_{1}\right)$ at $0{ }^{\circ} \mathrm{C}$ was calculated to be $5.98 \times 10^{-4} \mathrm{~s}$ ${ }^{1}$ while the rate of formation of $6 \mathbf{a}$ matched with the rate of the consumption of $4 \mathbf{a},{ }^{[8]}$ suggesting that these two processes are intermolecularly connected. In the same way, the corresponding reaction of $\mathbf{3 f}$ afforded $\mathbf{6 a}$ quantitatively in less than $15 \mathrm{~min}$ at $\left.0{ }^{\circ} \mathrm{C},{ }^{[8,14}\right]$ which illustrates the effect of a more sterically hindered $\mathrm{N}$ on the rate of the $\mathrm{C}\left(\mathrm{sp}^{2}\right)-\mathrm{C}(\mathrm{sp}) \mathrm{N}$ reductive elimination. Similarly, complex 3c reacted with TMSCN at $25{ }^{\circ} \mathrm{C}$ furnishing the corresponding arylgold(III) cyanide $\mathbf{4 c}$ (Scheme 3a). 4c was then converted to benzonitrile $6 \mathrm{c}$ at $25^{\circ} \mathrm{C}$. In this case, the first-order rate constant $\left(k_{2}\right)$ at $25^{\circ} \mathrm{C}$ was calculated to be $4.45 \times 10^{-4} \mathrm{~s}^{-1}$. These results highlight the strong effect played by the $\left(P^{\wedge} N\right)$ ligand in facilitating the formation of the new $\mathrm{C}\left(\mathrm{sp}^{2}\right)-\mathrm{C}(\mathrm{sp})$ bond, 
as the analogous reductive elimination in the case of a monoligated $\left(\mathrm{PPh}_{3}\right) \mathrm{AuArCN}_{2}$ complex $\left(\mathrm{Ar}=2,6-\mathrm{F}_{2}-\mathrm{C}_{6} \mathrm{H}_{3}\right)$ proceeds exclusively under thermal conditions (above $60^{\circ} \mathrm{C}$ ) over long periods of time. ${ }^{[15]}$ As for the more electron-deprived complex 3f, the $\mathrm{C}\left(\mathrm{sp}^{2}\right)-\mathrm{C}(\mathrm{sp})$ bond formation only occurred when the temperature is raised to $50{ }^{\circ} \mathrm{C}$ (Scheme $3 \mathrm{~b}$ ). In an analogous manner, the reaction of complexes $\mathbf{3 a}$ and $\mathbf{3 c}$ with methylpropiolate delivered the products of $\mathrm{C}\left(\mathrm{sp}^{2}\right)-\mathrm{C}(\mathrm{sp})$ reductive elimination $\mathbf{8 a}$ and $\mathbf{8 c}$ at ambient temperature in excellent yields. Interestingly, more electron-rich alkynes such as 1-ethynyl-(3,5bistrifluoromethyl)benzene and phenylacetylene also delivered the corresponding cross-coupling products $9 \mathrm{a}$ and $10 \mathrm{a}$ in 53 and $72 \%$ yield, respectively (Scheme $3 c$ ). In this case, the quantitative formation (MeDalPhos)gold(I)-acetylide $7 / \mathrm{HSbF}_{6}$ after reaction completion could be again confirmed through its independent preparation by reaction of (MeDalPhos)gold(I) acetate with methylpropiolate. ${ }^{[8]}$ These results are in line with those of the wellestablished $\mathrm{C}\left(\mathrm{sp}^{2}\right)-\mathrm{C}\left(\mathrm{sp}^{2}\right)$ and $\mathrm{C}\left(\mathrm{sp}^{3}\right)-\mathrm{C}\left(\mathrm{sp}^{3}\right)$ bond formation in phosphine ligated systems. ${ }^{[16]}$

\section{Conclusion}

Herein, we successfully synthesized, isolated and characterized a new family of stable bidentate $\left(\mathrm{P}^{\wedge} \mathrm{N}\right)$ arylgold(III) fluoride complexes. Crystallographic and computational DFT analysis revealed a significant ionic character of the Au-F bond which correlates to the geometry distortion induced by the ligand. These complexes, featuring an unprecedented P-Au-F system, were able to activate $\mathrm{C}(\mathrm{sp})$ ligands such as methylpropiolate and TMSCN enabling the study of the corresponding $\mathrm{C}\left(\mathrm{sp}^{2}\right)-\mathrm{C}(\mathrm{sp})$ reductive elimination. This reaction proceeds under mild reaction conditions at higher rates than those reported for analogous phosphine-based monodentate systems, thus highlighting the potential of this work to develop and/or improve existing gold(I)/gold(III) catalytic methods for the cross coupling of $\mathrm{C}\left(\mathrm{sp}^{2}\right)$ $\mathrm{C}(\mathrm{sp})$ bonds.

\section{Acknowledgements}

We thank the European Research Council (ERC Starting grant agreement no. 307948) and the Swiss National Science Foundation (SNF 200020_146853) for financial support.

Keywords: gold(III) • fluoride $\cdot$ ligand exchange $\cdot$ reductive elimination

[1] a) E. F. Murphy, R. Murugavel, H. W. Roesky, Chem. Rev. 1997, 97, 3425 - 3468; b) K. Fagnou, M. Lautens, Angew. Chem. Int. Ed. 2002 41, 26 - 47; Angew. Chem. 2002, 114, 26 - 49; c) J. E. Veltheer, P. Burger, R. G. Bergman, J. Am. Chem. Soc. 1995, 117, $12478-$ 12488; d) M. C. Pilon, V. V. Grushin, Organometallics 1998, 17, 1774 -1781 ; e) A. Yahav, I. Goldberg, A. Vigalok, J. Am. Chem. Soc. 2003, 125, 13634 - 13635; f) P. Nilsson, F. Plamper, O. F. Wendt, Organometallics 2003, 22, 5235-5242; g) V. V. Grushin, Acc. Chem. Res. 2010, 43, $160-171$; h) S. L. Fraser, M. Y. Antipin, V. N Khroustalyov, V. V Grushin, J. Am. Chem. Soc. 1997, 119, $4769-$ 4770.

[2] a) K. Yamamoto, J. Li, J. A. O. Garber, J. D. Rolfes, G. B. Boursalian J. C. Borghs, C. Genicot, J. Jacq, M. van Gastel, F. Neese, T. Ritter Nature 2018, 554, $511-514$; b) A. R. Mazzotti, M. G. Campbell, P. Tang, J. M. Murphy, T. Ritter, J. Am. Chem. Soc. 2013, 135, $14012-$
14015 ; c) T. Furuya, H. M. Kaiser, T. Ritter, Angew. Chem. Int. Ed. 2008, 47, 5993 - 5996; Angew. Chem. 2008, 120, 6082 - 6085; d) T. Furuya, T. Ritter, Org. Lett. 2009, 11, 2860 - 2863; e) K. L. Hull, W. Q. Anani, M. S. Sanford, J. Am. Chem. Soc. 2006, 128, 7134 7135; f) X. Wang, T. Mei, J. Yu, J. Am. Chem. Soc. 2009, 131, 7520 -7521 ; g) S. Qiu, T. Xu, J. Zhou, Y. Guo, G. Liu, J. Am. Chem. Soc 2010, 132, 2856 - 2857; h) T. Wu, G. Yin, G. Liu, J. Am. Chem. Soc 2009, 131, $16354-16355$; i) D. A. Watson, M. Su, G. Teverovskiy, Y. Zhang, J. Garcia-Fortanet, T. Kinzel, S. L. Buchwald, Science 2009, 325, 1661 - 1664; j) D. Gao, E. V Vinogradova, S. K. Nimmagadda, J. M. Medina, Y. Xiao, R. M. Suciu, B. F. Cravatt, K. M. Engle, J. Am. Chem. Soc. 2018, 140, $8069-8073$.

[3] a) H. Lee, J. Börgel, T. Ritter, Angew. Chem. Int. Ed. 2017, 56, 6966 - 6969; Angew. Chem. 2017, 127, 7070 - 7073; b) N. D. Ball, M. S. Sanford, J. Am. Chem. Soc. 2009, 131, 3796 - 3797; c) N. M. Camasso, M. H. Pérez-Temprano, M. S. Sanford, J. Am. Chem. Soc. 2014, 136, 12771 - 12775; d) I. M. Pendleton, M. H. Pérez-Temprano, M. S. Sanford, P. M. Zimmerman, J. Am. Chem. Soc. 2016, 138, 6049 -6060; e) E. A. Meucci, A. Ariafard, A. J. Canty, J. W. Kampf, M. S. Sanford, J. Am. Chem. Soc. 2019, 141, 13261 - 13267; f) C. C. Roberts, E. Chong, J. W. Kampf, A. J. Canty, A. Ariafard, M. S. Sanford, J. Am. Chem. Soc. 2019, 141, 19513-19520.

a) L. T. Ball, G. C. Lloyd-Jones, C. A. Russell, Science 2012, 337 1644 - 1648; b) T. J. A. Corrie, L. T. Ball, C. A. Russell, G. C. LloydJones, J. Am. Chem. Soc. 2017, 139, 245 - 254; c) A. Dahiya, C Fricke, F. Schoenebeck, J. Am. Chem. Soc. 2020, 142, $7754-7759$; d) Y. Yang, P. Antoni, M. Zimmer, K. Sekine, F. F. Mulks, L. Hu, L. Zhang, M. Rudolph, F. Rominger, A. S. K. Hashmi, Angew. Chem. Int. Ed. 2019, 58, 5129 - 5133; Angew. Chem. 2019, 131, 5183 - 5187; e) Y. Yang, J. SchießI, S. Zallouz, V. Göker, J. Gross, M. Rudolph, F. Rominger, A. S. K. Hashmi, Chem. Eur. J. 2019, 25, 9624 - 9628; f) A. Zeineddine, L. Estévez, S. Mallet-Ladeira, K. Miqueu, A. Amgoune, D. Bourissou, Nat. Commun. 2017, 8, 565; g) J. Rodriguez, A. Zeineddine, E. D. Sosa Carrizo, K. Miqueu, N. Saffon-Merceron, A. Amgoune, D. Bourissou, Chem. Sci. 2019, 10, 7183 - 7192 ; h) J. Rodriguez, N. Adet, N. Saffon-Merceron, D. Bourissou, Chem. Commun. 2020, 56, 94 - 97; i) T. de Haro, C. Nevado, J. Am. Chem. Soc. 2010, 132, 1512 - 1513; j) M. Hofer, A. Genoux, R. Kumar, C. Nevado, Angew. Chem. Int. Ed. 2017, 56, 1021 - 1025; Angew. Chem. 2017, 129, 1041 - 1045; k) M. Hofer, T. De Haro, E. Gómez Bengoa, A. Genoux, C. Nevado, Chem. Sci. 2019, 10, 8411 - 8420.

[5] a) G. Zhang, Y. Peng, L. Cui, L. Zhang, Angew. Chem. Int. Ed. 2009, 48, 3112-3115; Angew. Chem. 2009, 121, 3158-3161; b) G. Zhang, L. Cui, Y. Wang, L. Zhang, J. Am. Chem. Soc. 2010, 132, $1474-$ 1475 ; c) M. N. Hopkinson, A. Tessier, A. Salisbury, G. T. Giuffredi, L. E. Combettes, A. D. Gee, V. Gouverneur, Chem. Eur. J. 2010, 16, $4739-4743$; d) W. Wang, J. Jasinski, G. B. Hammond, B. Xu Angew. Chem. Int. Ed. 2010, 49, 7247 - 7252; Angew. Chem. 2010 122, 7405 - 7410; e) W. E. Brenzovich, J.-F. Brazeau, F. D. Toste, Org. Lett. 2010, 12, 4728 - 4731; f) E. Tkatchouk, N. P. Mankad, D. Benitez, W. A. Goddard, F. D. Toste, J. Am. Chem. Soc. 2011, 133, $14293-14300$; g) M. N. Hopkinson, J. E. Ross, G. T. Giuffredi, A D. Gee, V. Gouverneur, Org. Lett. 2010, 12, 4904 - 4907; h) A. Leyva-Pérez, A. Doménech, S. I. Al-Resayes, A. Corma, ACS Catal. 2012, 2, 121 - 126; i) D. Qian, J. Zhang, Beilstein J. Org. Chem. 2011, 7, $808-812$

[6] a) R. G. Pearson, J. Am. Chem. Soc. 1963, 85, 3533-3539; b) D. S. Laitar, P. Müller, T. G. Gray, J. P. Sadighi, Organometallics 2005, 24 $4503-4505$; c) D. Y. Melgarejo, G. M. Chiarella, J. P. Fackler, L. M. Perez, A. Rodrigue-Witchel, C. Reber, Inorg. Chem. 2011, 50, 4238 - 4240; d) N. P. Mankad, F. D. Toste, J. Am. Chem. Soc. 2010, 132 $12859-12861$; e) N. P. Mankad, F. D. Toste, Chem. Sci. 2012, 3 , 72 - 76; f) R. Kumar, A. Linden, C. Nevado, Angew. Chem. Int. Ed. 2015, 54, 14287 - 14290; Angew. Chem. 2015, 127, 14495 - 14498 g) R. Kumar, A. Linden, C. Nevado, J. Am. Chem. Soc. 2016, 138, 13790 - 13793; h) M. A. Ellwanger, S. Steinhauer, P. Golz, H. Beckers, A. Wiesner, B. Braun-Cula, T. Braun, S. Riedel, Chem. - A Eur. J. 2017, 23, 13501 - 13509; i) M. A. Ellwanger, S. Steinhauer, P. Golz, T. Braun, S. Riedel, Angew. Chem. Int. Ed. 2018, 57, 7210 - 7214; Angew. Chem. 2018, 130, 7328 - 7332; j) A. Pérez-Bitrián, M. Baya, J. M. Casas, A. Martín, B. Menjón, J. Orduna, Angew. Chem Int. Ed. 2018, 57, 6517 - 6521; Angew. Chem. 2018, 130, 6627 6631 ; k) M. Albayer, R. Corbo, J. L. Dutton, Chem. Commun. 2018 , $54,6832-6834$.

[7] a) M. Navarro, A. Toledo, M. Joost, A. Amgoune, S. Mallet-Ladeira, 
D. Bourissou, Chem. Commun. 2019, 55, 7974 - 7977 ; b) M Navarro, A. Toledo, S. Mallet-Ladeira, E. D. Sosa Carrizo, K. Miqueu, D. Bourissou, Chem. Sci. 2020, 11, $2750-2758$.

[8] For further information and additional control experiments, see the Supporting Information. CCDC-2013400 (2f), 2013404 (3a), 2013404 (3b), 2013405 (3d), 2013406 (3e), contain the supplementary crystallographic data for this paper. The data can be obtained free of charge from the Cambridge Crystallographic Data Centre via www.ccdc.cam.ac.uk/structures

[9] The counterion did not influence the value of the ${ }^{2} \mathrm{JP}$-F. Complex $3 \mathbf{a} / \mathrm{BF}_{4}$ was prepared and its ${ }^{2} \mathrm{~J}_{\mathrm{P}-\mathrm{F}}$ value $(100.5 \mathrm{~Hz})$ matches that obtained for the $3 \mathbf{a} / \mathrm{SbF}_{6}$ analogue reported in Figure 1 and Table 1.

[10] For examples of study on the effect of phosphine sized on two-bond coupling see: a) For ${ }^{13} \mathrm{C}-\mathrm{Au}-{ }^{31} \mathrm{P}$ : A. A. Isab, M. S. Hussain, M. N. Akhtar, M. I. M. Wazeer, A.R. Al-Arfaj, Polyhedron 1999, 18, 1401 1409 ; b) For ${ }^{15} \mathrm{~N}-\mathrm{Pd}-{ }^{31} \mathrm{P}$ : J. M. Dennis, N. A. White, R. Y. Liu, S. L. Buchwald, J. Am. Chem. Soc. 2018, 140, 4721.

[11] Different functionals and basis sets were tested in NPA analysis obtaining similar charge values. For further information, including NBO analysis on these systems, see the Supporting Information.

[12] a) A. Tamaki, S. A. Magennis, J. K. Kochi, J. Am. Chem. Soc. 1974, 96, 6140 - 6148; b) S. Komiya, T. A. Albright, R. Hoffmann, J. K. Kochi,. J. Am. Chem. Soc. 1976, 98, $7255-7265$; c) S. Komiya, J. K. Kochi, J. Am. Chem. Soc. 1976, 98, 7599 - 7607; d) P. L. Kuch, R. S. Tobias, J. Organomet. Chem. 1976, 122, 429 - 446; e) S. Komiya, A. Shibue, Organometallics 1985, 4, 684-687; J. Vicente, M. D. Bermúdez, J. Escribano, Organometallics 1991, 10, 3380 - 3384; f) W. J. Wolf, M. S. Winston, F. D. Toste, Nat. Chem. 2012, 6, $159-$ $164 ;$ g) K. Kang, S. Liu, T. Xu, D. Wang, X. Leng, R. Bai, Y. Lan, Q. Shen, Organometallics 2017, 36, $4727-4740$; h) A. Nijamudheen, S. Karmakar, A. Datta, Chem. Eur. J. 2014, 20, 14650 -14658; R. Bhattacharjee, A. Nijamudheen, A. Datta, Chem. Eur. J. 2017, 23, 4169 - 4179; i) L. Rocchigiani, J. Fernández-Cestau, P. H. M. Budzelaar, M. Bochmann, Chem. Eur. J. 2018, 24, 8893 - 8903.

[13] Complex $\mathbf{3 d}$ was chosen to prepare $4 \mathbf{d d}^{-13} \mathrm{C}_{C N}$ given its reduced reactivity towards reductive elimination. When $\mathbf{3 d}$ was treated with TMSCN- $\left\{{ }^{13} \mathrm{C}-C N\right\}$ at $25{ }^{\circ} \mathrm{C}, 4 \mathbf{4 d}-{ }^{13} \mathrm{C}_{C N}$ was formed displaying a characteristic strong trans ${ }^{2} \mathrm{~J}\left({ }^{11} \mathrm{P}-{ }^{13} \mathrm{C}\right)=134.3 \mathrm{~Hz}$ that confirms the trans relative position of the $\mathrm{CN}$ and $\mathrm{P}$ ligand across the metal center.

[14] The rate constant was estimated to be $k>4.6 \times 10^{-3} \mathrm{~s}^{-1}$ considering that the reaction reached up to $98.5 \%$ conversion in $15 \mathrm{~min}$ and it follows an irreversible first-order decay.

[15] A, Genoux, J. A. González, E. Merino, C. Nevado, Angew. Chem. Int. Ed. 2020, in print. The rate constant $k_{1}\left(0^{\circ} \mathrm{C}\right)$ was in the same range as the rate constant from gold(III) species bearing $\mathrm{PPh}_{3}$ ligand at $100{ }^{\circ} \mathrm{C}\left(k_{100}{ }^{\circ} \mathrm{C}=6.88 \times 10^{-4} \mathrm{~s}^{-1} \pm 2.34 \times 10^{-5} \mathrm{~s}^{-1}\right)$.

[16] Overall, the rates we observed are comparable to those previously reported for $\mathrm{C}\left(\mathrm{sp}^{3}\right)-\mathrm{C}\left(\mathrm{sp}^{3}\right)$ reductive elimination in cis$\mathrm{EtMe} 2 \mathrm{Au}\left(\mathrm{PPh}_{3}\right)$ and $\left[\mathrm{cis}-\left(\mathrm{CH}_{3}\right)_{2} \mathrm{Au}\left(\mathrm{PPh}_{3}\right)_{2}\right]\left(\mathrm{PF}_{6}\right) k_{\text {obs }} \approx 10^{-5}-10^{-3} \mathrm{~s}$ ${ }^{1}$ at $70^{\circ} \mathrm{C}$ (ref. 12a-d) as well as those reported for $\mathrm{C}\left(\mathrm{sp}^{2}\right)-\mathrm{C}\left(\mathrm{sp}^{2}\right)$ in $\left[c i s-\left(p-F-C_{6} \mathrm{H}_{4}\right)_{2} \mathrm{Au}\left(\mathrm{PPh}_{3}\right)\right](\mathrm{Cl}) k_{\text {obs }}=1.5 \times 10^{-4} \mathrm{~s}^{-1}$ at $-52^{\circ} \mathrm{C}$ (ref. $12 \mathrm{f}$ ). 


\section{Entry for the Table of Contents}

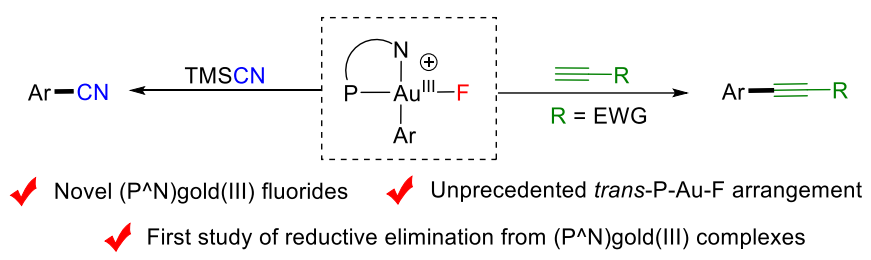

A new family of cationic bindenate $\left(P^{\wedge} N\right)$ gold(III) fluoride complexes has been prepared and characterized. Ligand exchange with $\mathrm{C}(\mathrm{sp})$ based nucleophiles enabled the first study of reactivity $\mathrm{C}\left(\mathrm{sp}^{2}\right)-\mathrm{C}(\mathrm{sp})$ reductive elimination on $\left(\mathrm{P}^{\wedge} \mathrm{N}\right)$ gold $(\mathrm{III})$ species. 